Prepared in cooperation with the U.S. Department of Energy, National Nuclear Security Administration, Nevada Site Office, Office of Environmental Management, under Interagency Agreement, DE-NA0001654/DE-AI52-12NA30865

\title{
T-COMP—A Suite of Programs for Extracting Transmissivity from MODFLOW Models
}

Chapter 54 of

Section A, Groundwater

\section{Book 6, Modeling Techniques}
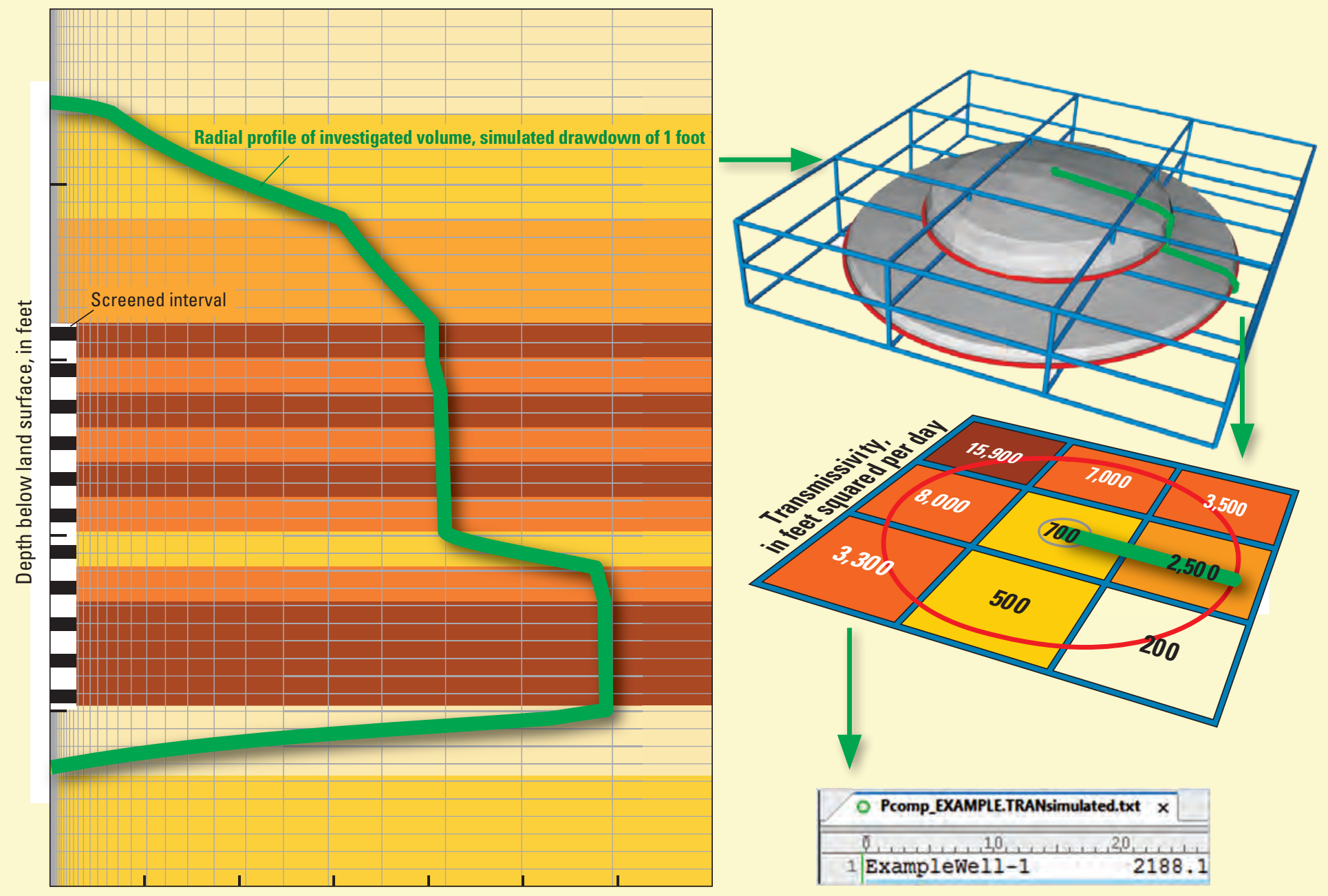

Radial distance from pumping well, in feet

Techniques and Methods 6-A54

U.S. Department of the Interior

U.S. Geological Survey 



\title{
T-COMP—A Suite of Programs for Extracting Transmissivity from MODFLOW Models
}

\author{
By Keith J. Halford
}

Chapter 54 of

Section A, Groundwater

Book 6, Modeling Techniques

Prepared in cooperation with the U.S. Department of Energy, National

Nuclear Security Administration, Nevada Site Office, Office of Environmental

Management, under Interagency Agreement, DE-NA0001654/DE-AI52-12NA30865

Techniques and Methods 6-A54 


\section{U.S. Department of the Interior SALLY JEWELL, Secretary}

\section{U.S. Geological Survey Suzette M. Kimball, Director}

\section{U.S. Geological Survey, Reston, Virginia: 2016}

For more information on the USGS - the Federal source for science about the Earth, its natural and living resources, natural hazards, and the environment—visit http://www.usgs.gov or call 1-888-ASK-USGS.

For an overview of USGS information products, including maps, imagery, and publications, visit http://www.usgs.gov/pubprod/.

Any use of trade, firm, or product names is for descriptive purposes only and does not imply endorsement by the U.S. Government.

Although this information product, for the most part, is in the public domain, it also may contain copyrighted materials as noted in the text. Permission to reproduce copyrighted items must be secured from the copyright owner.

Suggested citation:

Halford, K.J., 2016, T-COMP—A suite of programs for extracting transmissivity from MODFLOW models: U.S. Geological Survey Techniques and Methods, book 6, chap. A54, 17 p., http://dx.doi.org/10.3133/tm6A54.

ISSN 2328-7055 (online) 


\section{Preface}

This report documents software for sampling transmissivity observations from MODFLOW models. The software has been tested for accuracy by using multiple datasets. If users find or suspect errors, please contact the USGS.

Although every effort has been made by the USGS or the United States Government to ensure the T-COMP suite of programs is error free, errors may exist. The distribution of these programs does not constitute any warranty by the USGS, and no responsibility is assumed by the USGS in connection therewith. 


\section{Contents}

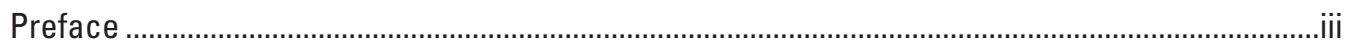

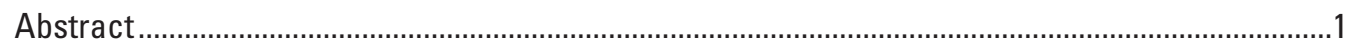

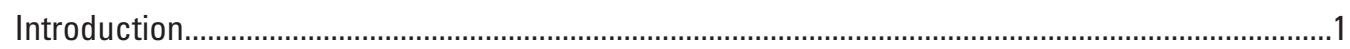

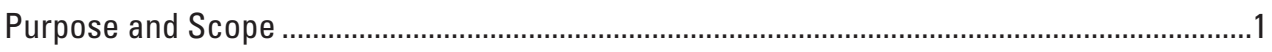

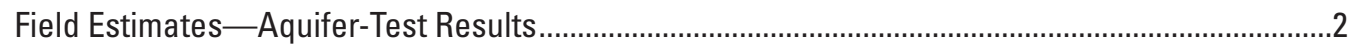

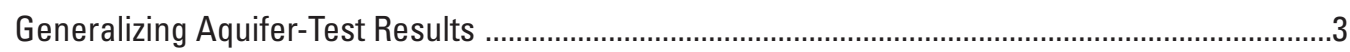

Constraining Simulated Transmissivity Estimates ...........................................................................

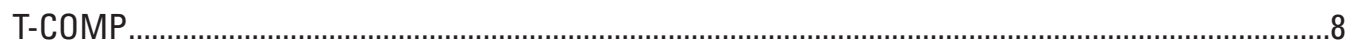

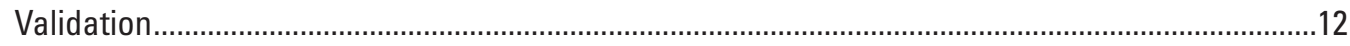

Simulation of Hypothetical Aquifer Systems.......................................................................... 12

Interpretation and Comparison .......................................................................................... 13

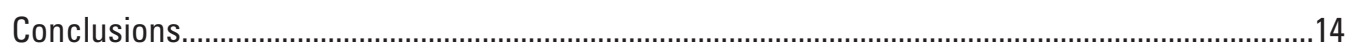

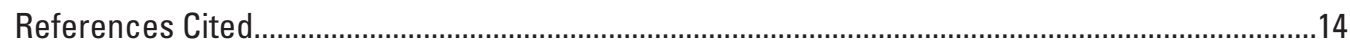

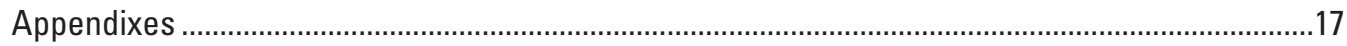

Appendix A. Aquifer Tests and Comparisons between Probability Distributions of Transmissivities from Hydraulic-Conductivity Limits and Aquifer-Test Results..........17

Appendix B. T-COMP Programs, Pre-Processing Tools, and an Example .............................17

Appendix C. Source Codes for T-COMP Programs ....................................................................17

Appendix D. T-COMP_Compare-A Workbook for Comparing Simulated Transmissivities Sampled with T-COMP to Specified Values .................................................................17

Appendix E. Results from T-COMP Verification .....................................................................17 


\section{Figures}

1. Semi-log plot showing Cooper-Jacob interpretation of a single-well aquifer test and potential uncertainty of estimated slope of drawdown.

2. Diagram showing minimum, maximum, geometric mean, and 95-percent confidence interval of log-hydraulic conductivities in 9 hydrogeologic units from 377 aquifer tests.

3. Graphs showing probability densities of transmissivity as defined by hydraulic-conductivity limits with a geologic column divided into 1, 2, 4, and 8 hydrogeologic units

4. Map showing location of aquifer tests in volcanic rocks around Nevada National Security Site, Nevada .6

5. Graphs showing probability densities of transmissivities as defined by hydraulic-conductivity limits and aquifer-test results, hydraulic-conductivity limits of hydrogeologic units at sites, and ranges of open intervals in selected wells

6. Graph showing probability densities of transmissivity near wells PM-1, ER-20-4 deep, and ER-EC-11 main, as defined by hydraulic-conductivity limits and aquifer-test results

7. Graphs showing comparison of most probable transmissivities from aquifer-test results and hydraulic-conductivity limits.

8. Graph showing vertically heterogeneous hydraulic-conductivity distribution and screen depth from drillers' log, discretization of radial site model, and simulated drawdown that defines profile of investigated volume

9. Graphs showing vertical distribution of hydraulic conductivity and well construction with simulated drawdown profile from site model and simulated lateral flow across drawdown profile from site model, simulated lateral flow from site model averaged by regional model layer, and lateral-flow threshold

10. Diagram showing intersection of investigated volume from an aquifer test with a model grid

11. Schematic of hypothetical aquifer systems, well constructions, regional model layers, and site model layers

12. Graph showing transmissivity specified in hypothetical models compared to transmissivity estimated with Cooper-Jacob method and sampled with T-COMP approach

13. Graph showing simulated drawdown from a site model of an unconfined aquifer analyzed with the Cooper-Jacob method at early and late times

\section{Table}

1. Hydraulic properties and well construction that were varied in hypothetical models ..12 


\section{Conversion Factors}

Inch/Pound to SI

\begin{tabular}{|c|c|c|}
\hline Multiply & By & To obtain \\
\hline \multicolumn{3}{|c|}{ Length } \\
\hline foot $(\mathrm{ft})$ & 0.3048 & meter $(\mathrm{m})$ \\
\hline mile (mi) & 1.609 & kilometer $(\mathrm{km})$ \\
\hline \multicolumn{3}{|c|}{ Area } \\
\hline square mile $\left(\mathrm{mi}^{2}\right)$ & 259.0 & hectare (ha) \\
\hline square mile $\left(\mathrm{mi}^{2}\right)$ & 2.590 & square kilometer $\left(\mathrm{km}^{2}\right)$ \\
\hline \multicolumn{3}{|c|}{ Volume } \\
\hline gallon (gal) & 3.785 & liter $(\mathrm{L})$ \\
\hline \multicolumn{3}{|c|}{ Flow rate } \\
\hline gallon per minute (gal/min) & 0.06309 & liter per second $(\mathrm{L} / \mathrm{s})$ \\
\hline \multicolumn{3}{|c|}{ Specific capacity } \\
\hline $\begin{array}{l}\text { gallon per minute per foot } \\
[(\mathrm{gal} / \mathrm{min}) / \mathrm{ft})]\end{array}$ & 0.2070 & $\begin{array}{l}\text { liter per second per meter } \\
{[(\mathrm{L} / \mathrm{s}) / \mathrm{m}]}\end{array}$ \\
\hline \multicolumn{3}{|c|}{ Transmissivity* } \\
\hline foot squared per day $\left(\mathrm{ft}^{2} / \mathrm{d}\right)$ & 0.09290 & meter squared per day $\left(\mathrm{m}^{2} / \mathrm{d}\right)$ \\
\hline
\end{tabular}

\section{Datum}

Horizontal coordinate information is referenced to the North American Datum of 1983 (NAD 83).

\section{Supplemental Information}

*Transmissivity: The standard unit for transmissivity is cubic foot per day per square foot times foot of aquifer thickness $\left[\left(\mathrm{ft}^{3} / \mathrm{d}\right) / \mathrm{ft}^{2}\right] \mathrm{ft}$. In this report, the mathematically reduced form, foot squared per day $\left(\mathrm{ft}^{2} / \mathrm{d}\right)$, is used for convenience. 



\title{
T-COMP_A Suite of Programs for Extracting Transmissivity from MODFLOW Models
}

\author{
By Keith J. Halford
}

\section{Abstract}

Simulated transmissivities are constrained poorly by assigning permissible ranges of hydraulic conductivities from aquifer-test results to hydrogeologic units in groundwater-flow models. These wide ranges are derived from interpretations of many aquifer tests that are categorized by hydrogeologic unit. Uncertainty is added where contributing thicknesses differ between field estimates and numerical models. Wide ranges of hydraulic conductivities and discordant thicknesses result in simulated transmissivities that frequently are much greater than aquifer-test results. Multiple orders of magnitude differences frequently occur between simulated and observed transmissivities where observed transmissivities are less than 1,000 feet squared per day.

Transmissivity observations from individual aquifer tests can constrain model calibration as head and flow observations do. This approach is superior to diluting aquifer-test results into generalized ranges of hydraulic conductivities. Observed and simulated transmissivities can be compared directly with T-COMP, a suite of three FORTRAN programs. Transmissivity observations require that simulated hydraulic conductivities and thicknesses in the volume investigated by an aquifer test be extracted and integrated into a simulated transmissivity. Transmissivities of MODFLOW model cells are sampled within the volume affected by an aquifer test as defined by a well-specific, radial-flow model of each aquifer test. Sampled transmissivities of model cells are averaged within a layer and summed across layers. Accuracy of the approach was tested with hypothetical, multiple-aquifer models where specified transmissivities ranged between 250 and 20,000 feet squared per day. More than 90 percent of simulated transmissivities were within a factor of 2 of specified transmissivities.

\section{Introduction}

Hydraulic-conductivity estimates in groundwaterflow models typically are constrained by a range for each hydrogeologic unit. These often are wide ranges and are derived from interpretations of many aquifer tests categorized by hydrogeologic unit. Uncertainty is added to these ranges where hydraulic-conductivity estimates derived from aquifer tests use contributing thicknesses that differ from simulated aquifer thicknesses in a numerical model.
Transmissivity observations from individual aquifer tests constrain model calibration better than hydraulic-conductivity ranges assigned to hydrogeologic units because simulated transmissivity and aquifer-test results are compared directly. Transmissivity comparisons require that simulated thicknesses and hydraulic conductivities for the volume investigated by the aquifer test be extracted from a model and integrated into a simulated transmissivity. Transmissivity observations have been ignored primarily because sampling simulated transmissivities becomes more difficult with finer discretization.

A suite of programs called T-COMP have been developed to sample simulated transmissivities easily from regional MODFLOW (Harbaugh, 2005) models. T-COMP provides modelers with tools that simplify comparing simulated transmissivities to aquifer-test results during model calibration. T-COMP addresses the technical difficulties of defining a volume within the groundwater model that is consistent with the volume of aquifer sampled during an aquifer test. T-COMP reduces this difficulty by defining the radius sampled during an aquifer test as the drawdown at the end of an aquifer test. A minimum drawdown threshold separates significant drawdown from noise. Regional model cells in the volume of significant drawdown contribute to a simulated transmissivity, where transmissivities from model cells are averaged within a layer and summed between layers. Simulated transmissivities are sampled quickly because computationally intensive processes occur in separate programs that are not called during model calibration.

\section{Purpose and Scope}

The purpose of this project is to document rationale, methodology, and FORTRAN programs for comparing field-estimated and simulated transmissivity. Inherent bias is demonstrated when groundwater-flow models are calibrated by constraining hydrogeologic units with a range of hydraulic conductivities. A consistent procedure that uses radial-profile models to determine hydrogeologic units contributing to aquifer tests is documented. These procedures are implemented through a suite of three FORTRAN programs known as T-COMP. The T-COMP approach was validated with hypothetical aquifer systems where hydraulic properties were specified and known. 


\section{Field Estimates-Aquifer-Test Results}

Transmissivity is the only hydraulic property that can be estimated reasonably from single-well aquifer tests (Hanson and Nishikawa, 1996; Halford and others, 2006) and is inversely proportional to the slope of water-level change on a semi-log plot (fig. 1). Transmissivity is the principal hydraulic property estimated for most tests, because most pumping aquifer tests are limited to a single well. For example, 75 percent of 73 pumping aquifer tests that were interpreted by U.S. Geological Survey (USGS) personnel in Nevada between 2003 and 2013 were single-well aquifer tests (U.S. Geological Survey, 2013, appendix A). Estimable hydraulic properties typically expand to include storage coefficient where drawdowns in pumping and observation wells are interpreted. Other hydraulic properties, such as vertical-to-horizontal anisotropy and specific yield, frequently remain non-unique with few observation wells and limited volumes of pumping (Halford and others, 2006).

About 90 percent of transmissivity estimates from single-well aquifer tests are within a factor of three of actual conditions (Halford and others, 2006). This finding was supported by analyzing drawdowns from 628 simulated single-well tests where effects of vertical anisotropy, partial penetration, specific yield, and interpretive technique were investigated in aquifers with transmissivities between 100 and $100,000 \mathrm{ft}^{2} / \mathrm{d}$.
Heterogeneous hydraulic properties minimally affect mean transmissivity estimates from aquifer tests. For example, transmissivity estimates from leaky analytical solutions and mean transmissivity of a heterogeneous distribution differed by less than a factor of 1.6 where discrete transmissivities in the synthetic distribution ranged three orders of magnitude (Trinchero and others, 2008). Hydraulic tomography investigations in field applications (Straface and others, 2007) and synthetic studies (Bohling and Butler, 2010) demonstrate that mean transmissivity estimates vary little whereas estimated hydraulic-property distributions remain non-unique. Transmissivity estimates from multiple interfering aquifer tests in each study differed by less than a factor of 2, whereas discrete transmissivities in estimated and specified distributions ranged between three and seven orders of magnitude (Straface and others, 2007; Bohling and Butler, 2010).

Transmissivity estimates are more certain than hydraulic conductivity estimates, because an often unknown contributing thickness does not have to be assumed and specified. Estimates from single-well aquifer tests where transmissivity exceeds $3,000 \mathrm{ft}^{2} / \mathrm{d}$ reflect the contributing thickness of the entire aquifer (Halford and others, 2006). The contributing thickness approaches the length of the screened interval where transmissivity is less than $100 \mathrm{ft}^{2} / \mathrm{d}$. Contributing thicknesses frequently are unknown because wells partially penetrate aquifer systems.

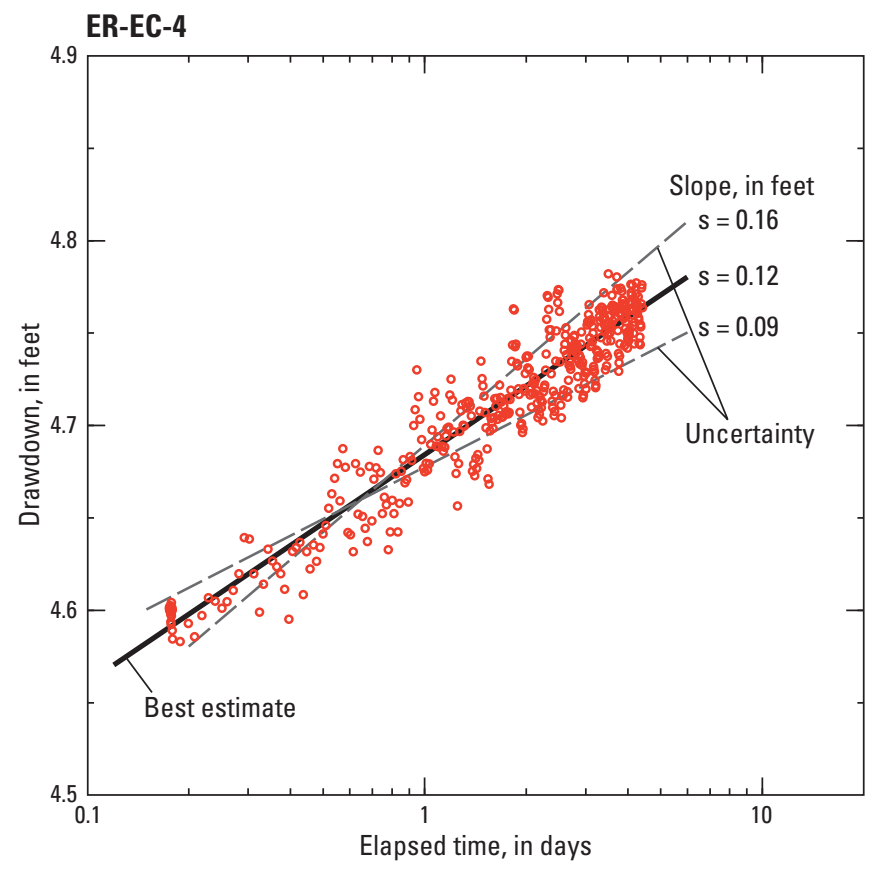

Figure 1. Semi-log plot showing Cooper-Jacob interpretation of a single-well aquifer test and potential uncertainty of estimated slope of drawdown. 


\section{Generalizing Aquifer-Test Results}

Field estimates of transmissivity frequently are normalized to hydraulic-conductivity estimates and categorized by rock units (Heath, 1983). Rock units typically have been defined by broad classes such as unconsolidated sediments, sedimentary, and crystalline and subdivided further by observable traits such as grain size, sorting, cementing, and fracturing (Domenico and Schwartz, 1990). Hydraulic conductivity of unconsolidated sediments correlates somewhat with grain size and sorting, but hydraulic conductivities typically range a few orders of magnitude in each rock unit.
Hydrogeologic units have been defined in southern Nevada to better associate rock units with hydraulic properties. Hydrogeologic units differ from rock units because transmissive and water-storage properties are considered directly in grouping (Laczniak and others, 1996). Belcher and others (2002) categorized results from hundreds of aquifer tests to define expected hydraulic conductivities of hydrogeologic units in the Death Valley regional-flow system (fig. 2). Hydraulic conductivities were estimated by dividing field estimates of transmissivity by the length of open intervals (Belcher and others, 2001, p. 13). Equating aquifer thickness with length of open intervals was a noted limitation along with incomplete lithologic characterization and sampling bias (Belcher and others, 2002).

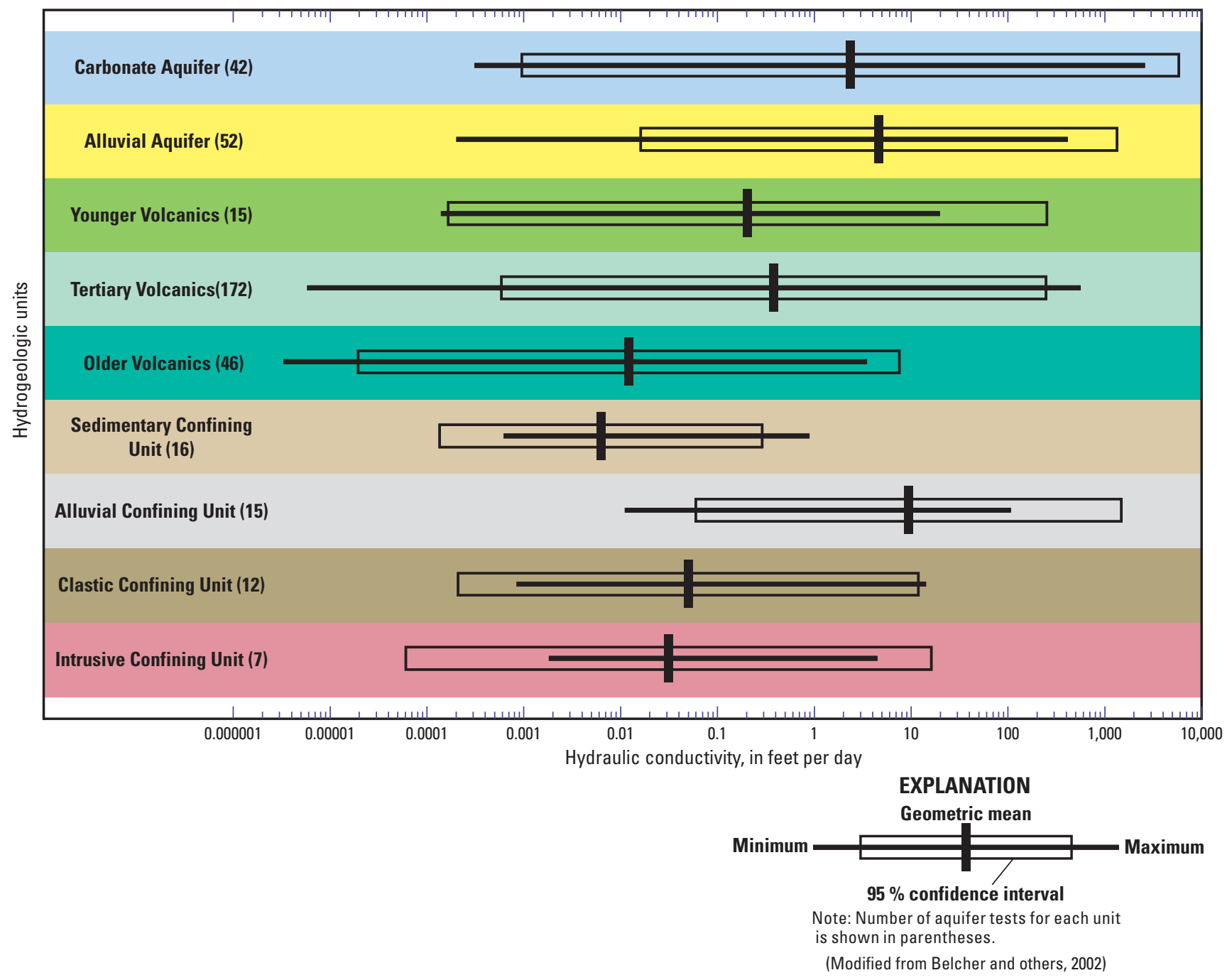

Figure 2. Minimum, maximum, geometric mean, and 95-percent confidence interval of log-hydraulic conductivities in 9 hydrogeologic units from 377 aquifer tests. 
Hydraulic-conductivity distributions of hydrogeologic units in the Death Valley regional-flow system have informed many groundwater-flow studies in the Great Basin other than the Death Valley regional groundwater-flow model (Belcher, 2004). Flow and transport investigations of radionuclide migration from Pahute Mesa (Stoller-Navarro Joint Venture, 2006), Yucca Mountain (Sandia National Laboratories, 2007), and Yucca Flat (Navarro-Intera, 2013), in part, used these hydraulic-conductivity distributions (fig. 2). Similar hydrogeologic units and hydraulic-conductivity distributions constrained hydraulic conductivity estimates in an investigation of potential effects of groundwater development in eastern Nevada (Southern Nevada Water Authority, 2009). Groundwater-flow systems at the Nevada Nuclear Security Site (NNSS) were synthesized in part from hydrogeologic units that were defined for the Death Valley regional-flow analysis (Fenelon and others, 2010).

\section{Constraining Simulated Transmissivity Estimates}

Transmissivities in groundwater-flow models typically are constrained indirectly by permissible ranges of hydraulic conductivities for hydrogeologic units during calibration. Hydraulic conductivities commonly are distributed through models with hydrogeologic units and are changed within permissible ranges. Permissible ranges of hydraulic conductivities for hydrogeologic units result from categorization studies such as Belcher and others

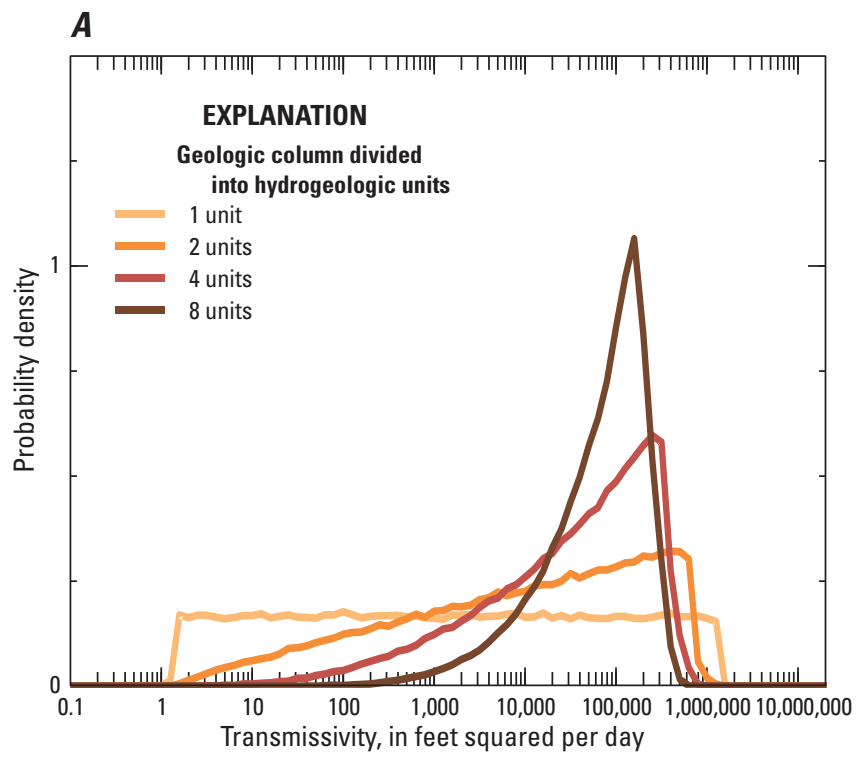

(2002). For studies in the Great Basin, permissible ranges for hydrogeologic units have been defined by minimum and maximum hydraulic conductivities (Belcher, 2004; Sandia National Laboratories, 2007; Southern Nevada Water Authority, 2009), and 95-percent confidence intervals (Stoller-Navarro Joint Venture, 2006; Brooks and others, 2014).

Permissible transmissivities from indirect constraints can be described with a probability distribution that is estimated from permissible ranges of hydraulic conductivities and specified thicknesses of hydrogeologic units. A potential transmissivity of a hydrogeologic unit at a mapped location is the product of thickness times a hydraulic conductivity that was sampled randomly from a log-normal range of permissible values. Potential simulated transmissivity is the summation of potential transmissivities for all hydrogeologic units at a mapped location. Probability distribution of transmissivities at a mapped location results from many potential simulated transmissivity realizations and is discussed herein as hydraulic-conductivity limits.

Hydraulic-conductivity limits range in shape from a square wave to skewed triangles (fig. 3). A square wave results from a single hydrogeologic unit at a mapped location that ranges between minimum and maximum permissible hydraulic conductivity times the aquifer thickness. The square wave rises at the minimum transmissivity and falls at the maximum transmissivity (fig. $3 A$ ). Subdividing a single hydrogeologic unit into multiple hydrogeologic units creates a complex probability distribution that approximates a triangle and is skewed towards greater transmissivities.

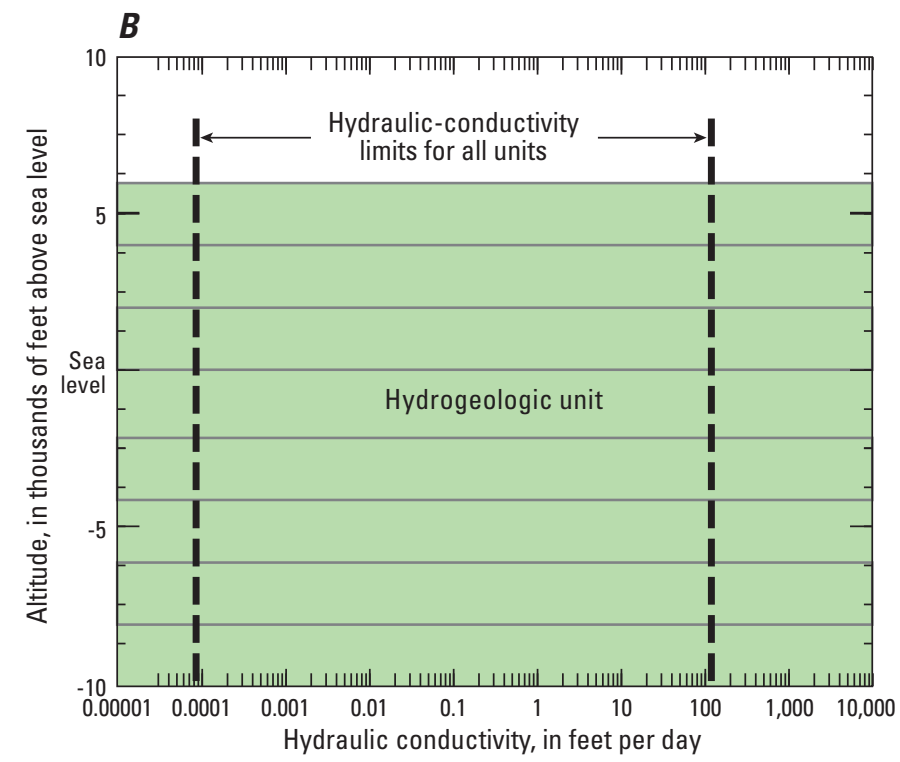

Figure 3. Probability densities of transmissivity $(A)$ as defined by hydraulic-conductivity limits $(B)$ with a geologic column divided into 1, 2, 4, and 8 hydrogeologic units. 
For example, a $15,000-\mathrm{ft}$ thick interval is subdivided into multiple hydrogeologic units where permissible hydraulic conductivities range between 0.0001 and $100 \mathrm{ft} / \mathrm{d}$ in all resulting hydrogeologic units (fig. $3 B$ ). Hydraulic-conductivity limits where the interval is defined as a single hydrogeologic unit would be a uniform probability density of 0.167 from 1.5 to $1,500,000 \mathrm{ft}^{2} / \mathrm{d}$ and a probability density of 0 outside the interval (fig. $3 A, 1$ unit). Subdividing the geologic column into two hydrogeologic units increases the maximum probability density to 0.27 with a most probable transmissivity of 400,000 ft²/d (fig. $3 A, 2$ units). Further subdividing the geologic column into eight hydrogeologic units increases the maximum probability density to 1.06 with a most probable transmissivity of $160,000 \mathrm{ft}^{2} / \mathrm{d}$ (fig. $3 A, 8$ units).

More hydrogeologic units in a geologic column skew the probability distribution, because the likelihood of encountering a transmissive hydrogeologic unit increases. Additional hydrogeologic units decrease the most probable transmissivity because thicknesses of transmissive intervals decrease (fig. 3). Skewing results from transmissivity being computed with hydraulic conductivities, not log-transformed values. This same process also occurs during calibration as estimated log-hydraulic conductivities are transformed to hydraulic conductivities and transmissivities are computed in groundwater-flow models.

Probability distributions of transmissivities were computed at aquifer-test sites near the NNSS so that hydraulic-conductivity limits could be compared to aquifer-test results (fig. 4). Permissible ranges of hydraulic conductivities differed between hydrogeologic units and were defined by the 95-percent confidence interval (fig. 2). Hydrogeologic units vertically extended from the water table to $13,000 \mathrm{ft}$ below sea level and laterally covered the Death Valley regional system (Belcher, 2004). Probability distributions of transmissivities at aquifer test sites were computed with 1,000,000 realizations (appendix A).

Triangular probability distributions that skew towards greater transmissivities occurred at all 49 sites (fig. 4). Probability distributions of transmissivities from hydraulicconductivity limits in ER-EC-4, ER-EC-2A, and UE-20f were typical (fig. 5). All predict simulated transmissivities that are more likely to range between 1,000 and $1,000,000 \mathrm{ft}^{2} / \mathrm{d}$. A transmissivity of about $100,000 \mathrm{ft}^{2} / \mathrm{d}$ is most likely in all three examples.

A probability distribution of transmissivities also can be estimated directly from aquifer-test results (fig. 5). Distributions are log-normal for single-well tests because uncertainties in transmissivity estimates are proportional to errors in discharge measurements and inversely proportional to errors in estimated slopes (fig. 1). For example, the probability distribution directly from ER-EC-2A (fig. 4) aquifer-test results centers on a transmissivity of $200 \mathrm{ft}^{2} / \mathrm{d}$ with a 95-percent confidence that transmissivity is between 100 and $400 \mathrm{ft}^{2} / \mathrm{d}$.

Probability distributions of transmissivities from hydraulic-conductivity limits do not honor individual or aggregate aquifer-test results (fig. 6). Probability distributions of transmissivities from hydraulic-conductivity limits consistently are skewed greater than aquifer-test results and permissible ranges span multiple orders of magnitude. Differences in hydrogeologic unit distributions between well sites minimally affect probability distributions of transmissivities. Probability distributions of transmissivities from hydraulic-conductivity limits from three wells differ by less than two orders of magnitude, while aquifer-tests results show transmissivities differ by more than four orders of magnitude (fig. 6). The relative ranking of transmissivity also is not predicted correctly by probability distributions of transmissivities from hydraulic-conductivity limits. For example, hydraulic-conductivity limits predict the greatest transmissivity at well PM-1 (76-7,563 ft; fig. 4) while aquifertest results demonstrate the lowest transmissivity occurs at this site.

The most probable transmissivity at a site is predicted poorly by hydraulic-conductivity limits (fig. 7), where the coefficient of determination is 0.03 for 49 sites (appendix A). Most probable transmissivity from hydraulic-conductivity limits averaged $60,000 \mathrm{ft}^{2} / \mathrm{d}$, whereas results from aquifer tests averaged $1,000 \mathrm{ft}^{2} / \mathrm{d}$. Predictive errors increased greatly where transmissivity estimates from aquifer tests were less than $5,000 \mathrm{ft}^{2} / \mathrm{d}$. Some of these errors can be attributed to differences in contributing thicknesses that averaged 2,200 and $17,300 \mathrm{ft}$ for aquifer tests and hydraulic-conductivity limits, respectively. Most probable transmissivity estimates of 30 and $140,000 \mathrm{ft}^{2} / \mathrm{d}$ from aquifer tests and hydraulic-conductivity limits, respectively, in well UE-20f (4,456-13,686 ft; fig. 5) suggest that differences in contributing thicknesses are a minor source of error. This is because the open interval of well UE-20f $(4,456-13,686 \mathrm{ft})$ exceeded 9,000 ft, which is similar to the contributing thickness of $17,464 \mathrm{ft}$ that was used for the hydraulic-conductivity limits estimate.

Probability of estimating ranges of transmissivities during model calibration will differ from probability distribution from hydraulic-conductivity limits. Water level, discharge, prior information, and other observations will inform hydraulic-conductivity estimates if simulated responses are sensitive to changes in these hydraulic-conductivity estimates. Constraining transmissivity estimates in groundwater-flow models with hydraulic-conductivity limits approaches random sampling as model sensitivity diminishes. 


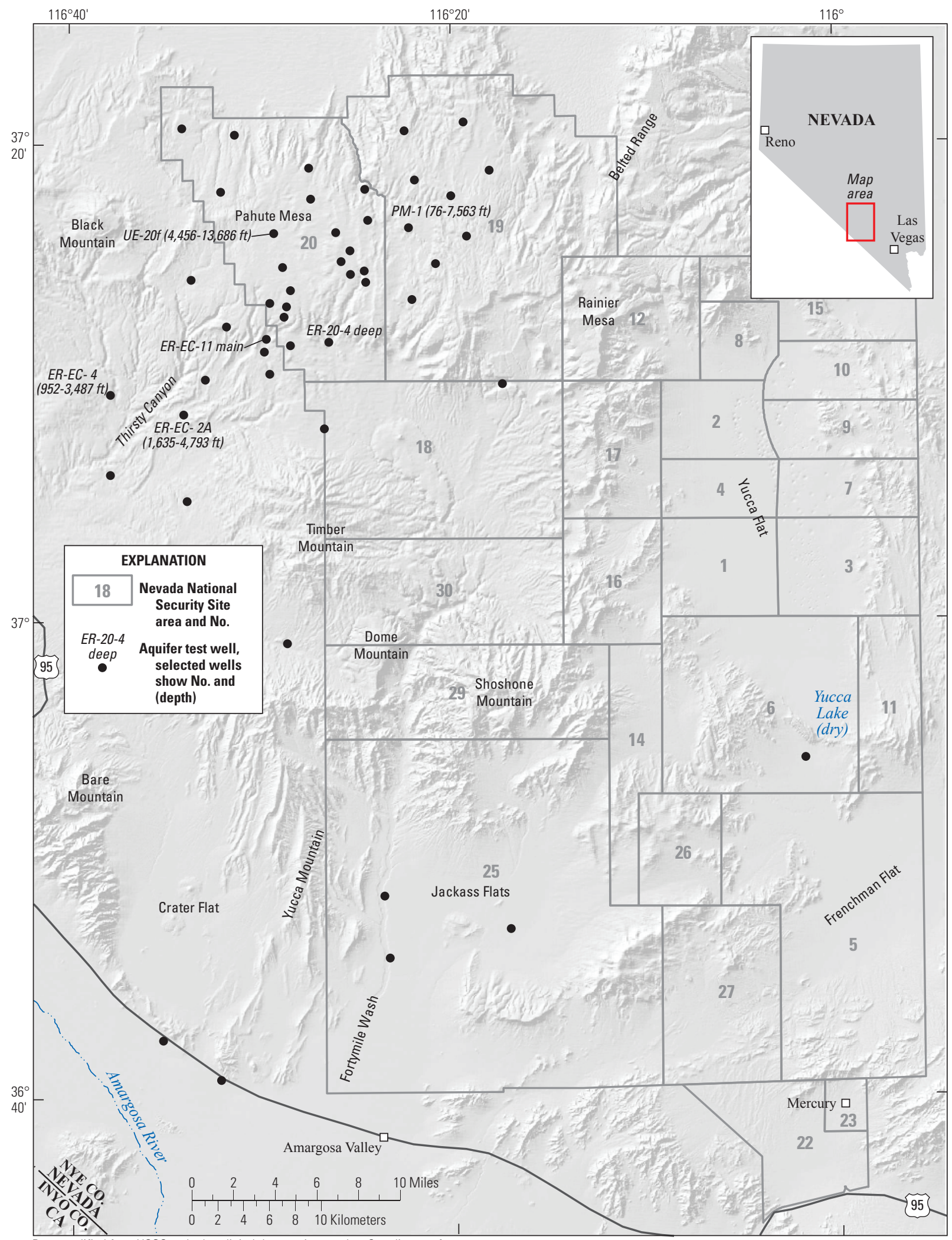

Base modified from USGS and other digital data, various scales. Coordinate reference system: Nevada State Plane Central, FIPS 2702, datum is North American Datum of 1983

Figure 4. Location of aquifer tests in volcanic rocks around Nevada National Security Site, Nevada. 
ER-EC- $4(952-3,487 \mathrm{ft})$

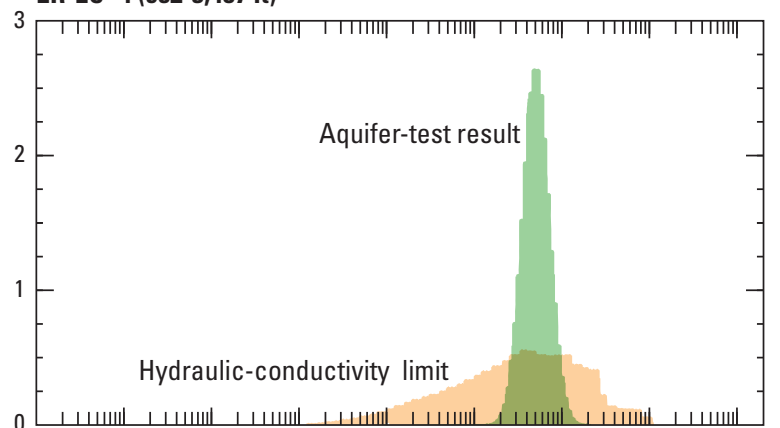

ER-EC- $2 A(1,635-4,793 \mathrm{ft})$

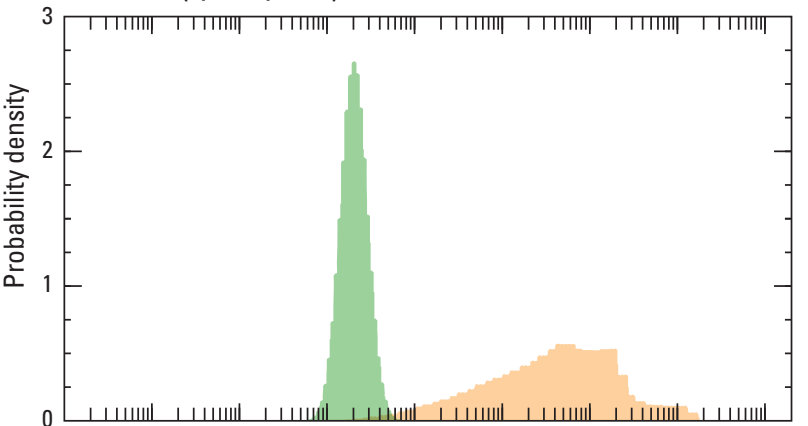

UE-20f $(4,456-13,686 \mathrm{ft})$

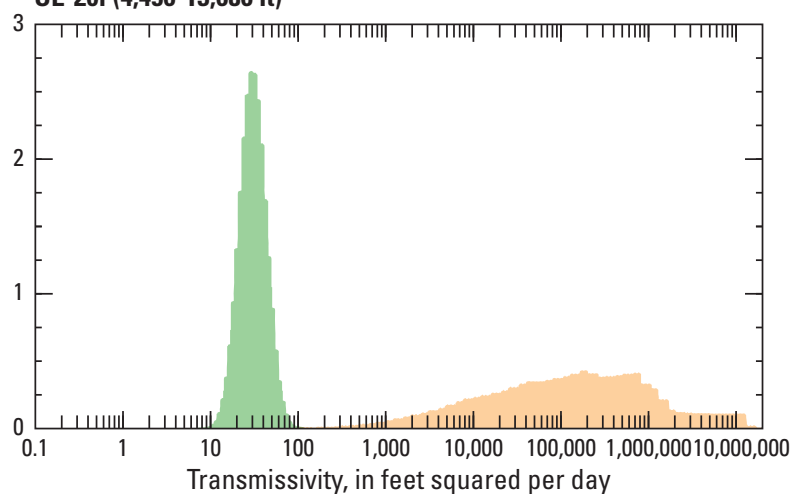

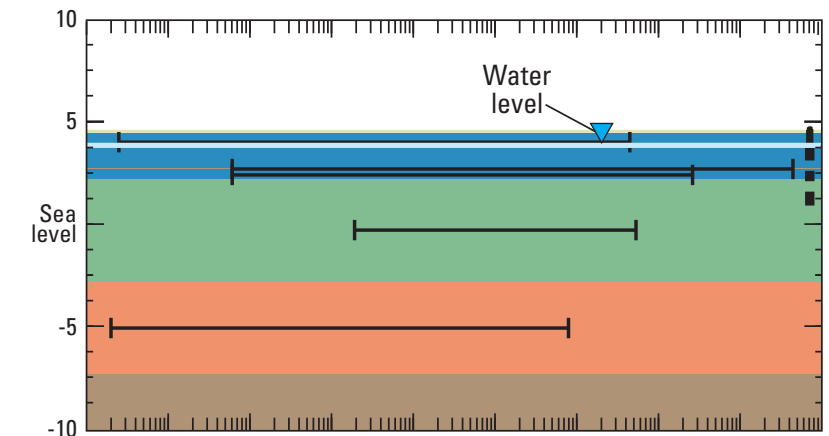
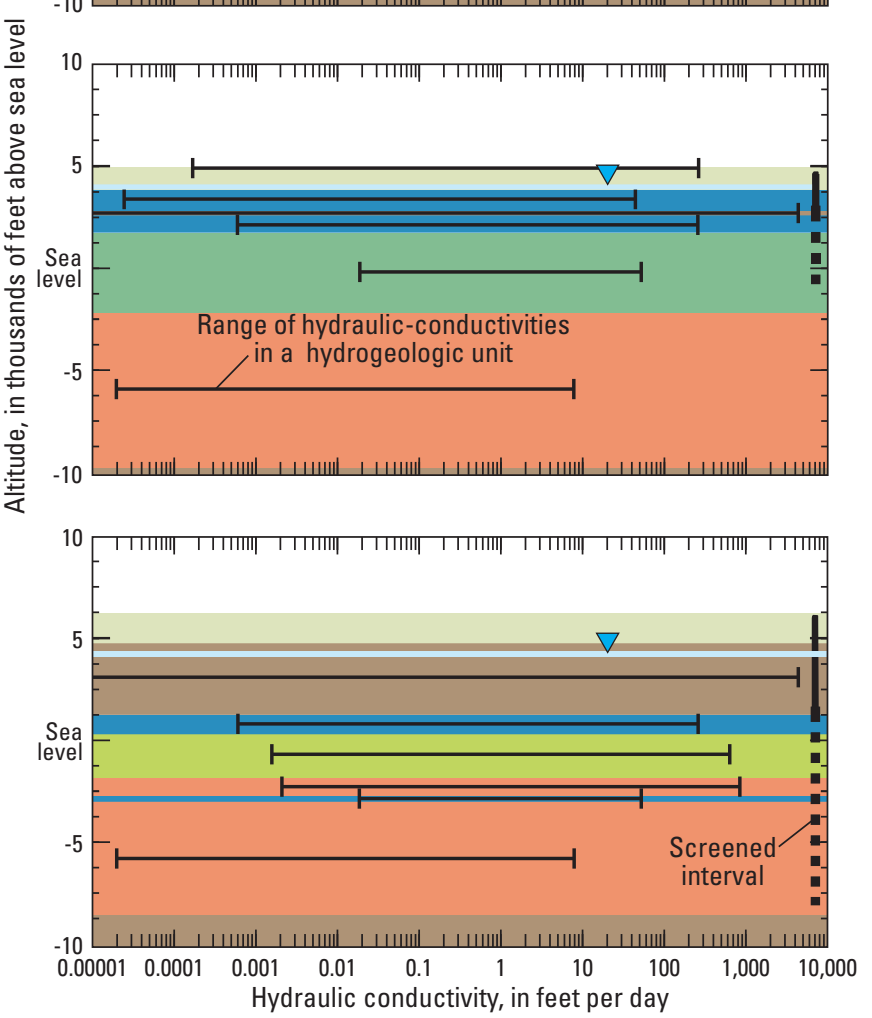

Note: Shaded areas are hydrogeologic units

Figure 5. Probability densities of transmissivities as defined by hydraulic-conductivity limits and aquifer-test results, hydraulic-conductivity limits of hydrogeologic units at sites, and ranges of open intervals in selected wells. 


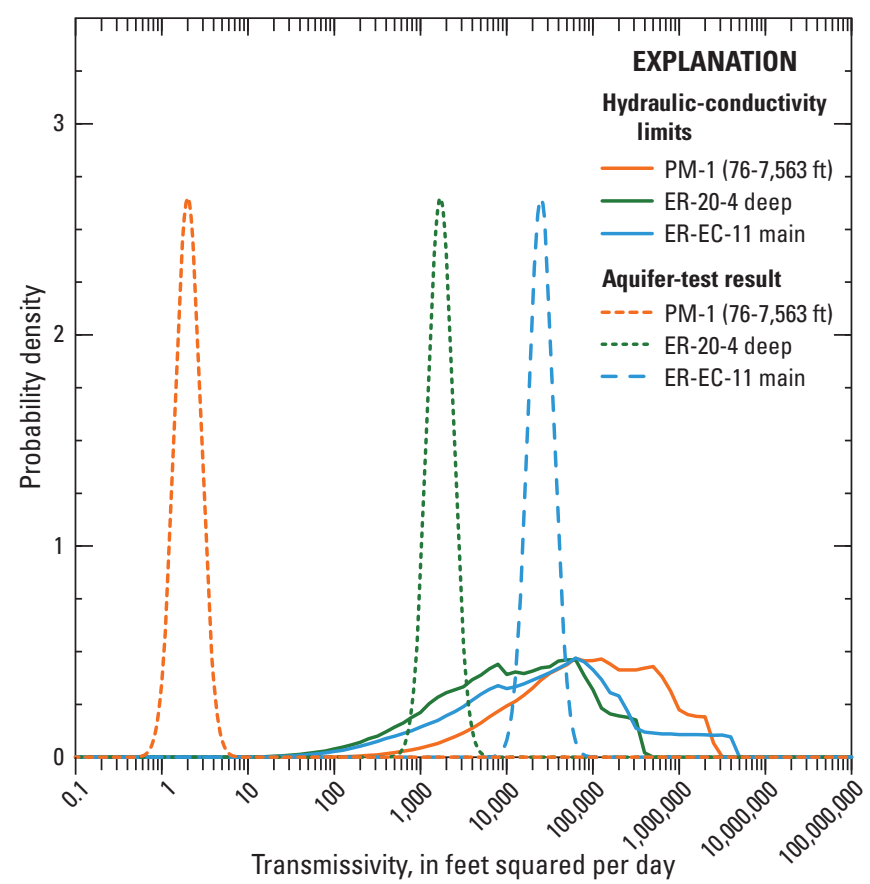

Figure 6. Probability densities of transmissivity near wells PM-1 (76-7,663 feet), ER-20-4 deep, and ER-EC-11 main, as defined by hydraulic-conductivity limits and aquifer-test results.

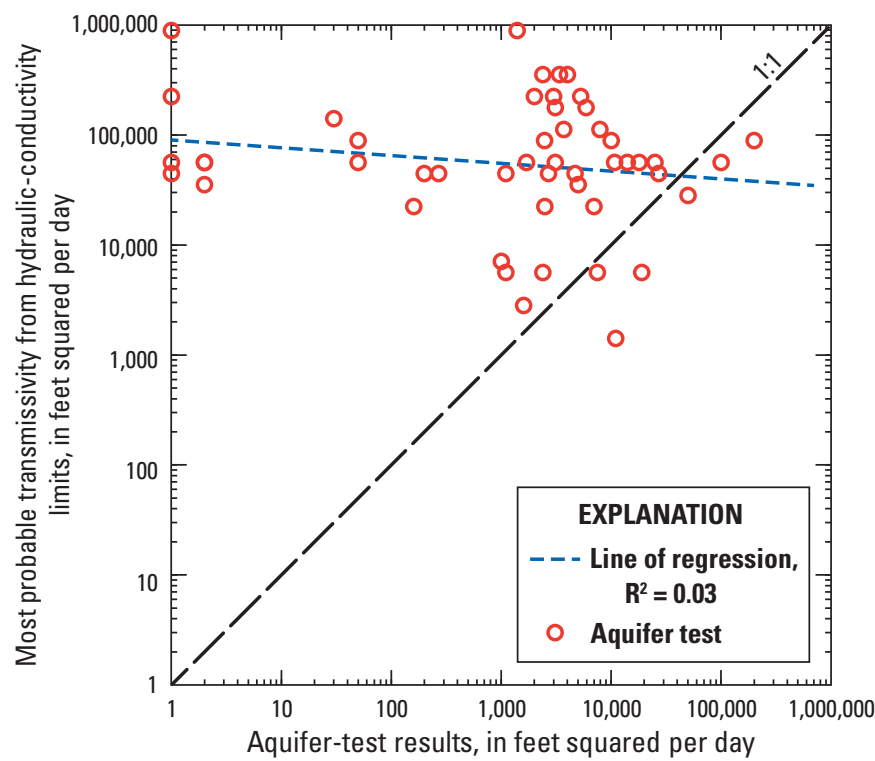

Figure 7. Comparison of most probable transmissivities from aquifer-test results and hydraulic-conductivity limits.
Aquifer-test results can best constrain calibration of groundwater-flow models as transmissivity observations because fewer assumptions are made. Simulated thicknesses and hydraulic conductivities of hydrogeologic units are known within the volume that is sampled from a model. This avoids assuming contributing thicknesses and differences in hydraulic conductivities between hydrogeologic units where aquifer-test results are reduced to hydraulic-conductivity estimates.

Simulated transmissivities are sampled from a groundwaterflow model and compared directly to aquifer-test results. This approach preserves known transmissivities without artificially adding or eliminating variability in simulated hydraulic-conductivity distributions.

Simulated transmissivities below depths investigated with aquifer tests only can be constrained with professional judgment. Hydraulic-conductivity limits explicitly define a possible range of transmissivities, but this assumes that aggregate aquifer-test results apply to the entire simulated thickness. For example, aquifer tests investigated the upper 2,000 ft of the Death Valley Regional Flow System and defined permissible ranges of hydraulic conductivities for hydrogeologic units (fig. 2). Saturated thicknesses of multiple groundwater-flow models extended far deeper to depths greater than 17,000 $\mathrm{ft}$ below the water table (Belcher and others, 2004; Stoller-Navarro Joint Venture, 2006; Sandia National Laboratories, 2007; Southern Nevada Water Authority, 2009; Navarro-Intera, 2013; Brooks and others, 2014). Considerable extrapolation occurred as these estimates were projected from 2,000 to $20,000 \mathrm{ft}$ below the water table. Extrapolation still occurs if transmissivity observations are compared during calibration because aquifer tests do not measurably perturb the entire aquifer.

\section{T-COMP}

T-COMP is a suite of three FORTRAN programs that: (1) determine volumes of aquifers investigated by aquifer tests; (2) identifies MODFLOW cells that are part of transmissivity observations; and (3) samples simulated transmissivities from a MODFLOW model for comparison to field estimates (appendix B). Simulation of investigated volumes and identification of affected cells requires some level of subjectivity and professional judgment. Simulated transmissivities are computed quickly because sampling occurs during model calibration. Partitioning these tasks into separate programs achieves these goals.

Two classes of MODFLOW models are associated with the T-COMP programs, regional and site, so that each class must be named explicitly. Simulated transmissivities typically are sampled from a model and used as observations that constrain calibration. This model will be referred to as a regional model regardless of extent or discretization. 
Investigated volumes of aquifer tests are estimated with radial flow models that simulate flow to a pumped well that penetrates a vertically heterogeneous hydraulic-conductivity distribution. These models are created by a T-COMP program for each aquifer test and will be referred to as site models.

Hydraulic conductivities in site models are distributed vertically either directly or by lithologic classifications (fig. 8). Well construction, pumping duration, discharge rate, and static depth to water are specified for each aquifer test. Each site model is created with information from the pumped well and vertically discretized to honor well construction and local lithology. Horizontal discretization expands radially from a specified wellbore radius to the radial extent of a site model in a user-specified number of columns (Langevin, 2008). Site models are discretized vertically with a uniform thickness that is user specified. The program T-COMP_Create creates all site models and a single batch file that simulates drawdowns at all aquifer-test sites (appendix C).

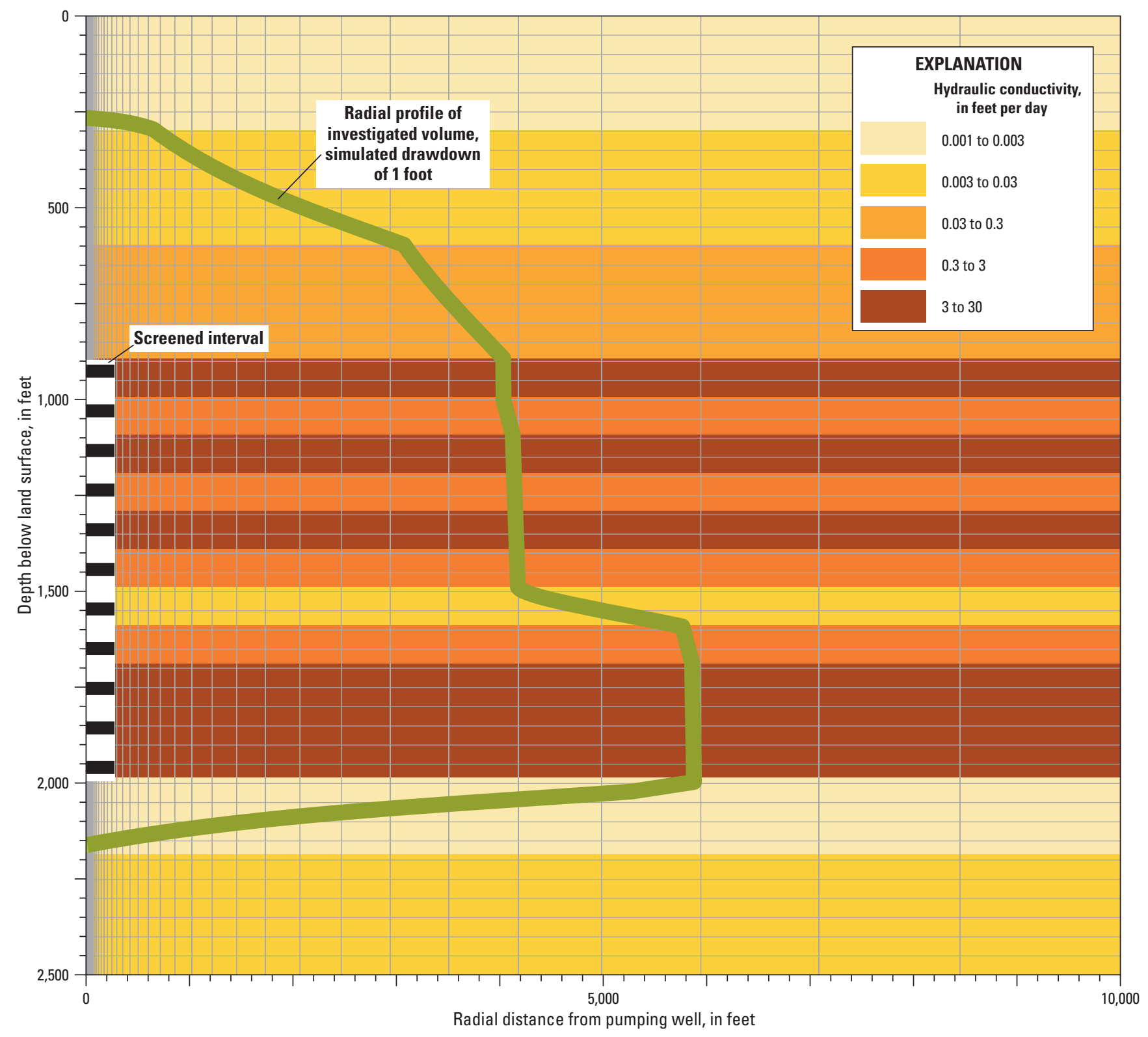

Figure 8. Vertically heterogeneous hydraulic-conductivity distribution and screen depth from drillers' log, discretization of radial site model, and simulated drawdown that defines profile of investigated volume. 
Site models simulate an axisymmetric, radial geometry in a one layer MODFLOW model (Harbaugh, 2005). The horizontal dimension is represented by columns and the vertical dimension is represented by rows, so that the one MODFLOW layer is conceptually flipped to the vertical position (Anderson and Woessner 1992, p. 175-176). The production well in each model was simulated as a high conductivity zone where water was removed from the uppermost cell and flow was apportioned within MODFLOW (Halford and others, 2006). Pumping wells were located in column 1, annular fill in column 2, and aquifer material was specified in columns 3 and greater. Lateral boundaries are specified as no flow. Initial heads of 0 are specified because no drawdown has occurred. Radial flow in site models is simulated by assigning a layer thickness of $2 \pi r_{\mathrm{i}}$ to simulate radial flow where $r_{\mathrm{i}}$ is the distance from the outer edge of the first column to the center of the $i^{\text {th }}$ column. This is equivalent to the radial distance between the pumping well and the $i^{\text {th }}$ column (Langevin, 2008).

Simulated transmissivity in a regional model cell is estimated from computed conductances between cells along rows and columns. This is because MODFLOW solves flow equations with inter-cell conductances that can be defined with multiple MODFLOW packages. For example, transmissivity of a cell might be assigned initially with hydraulic conductivity and cell elevations from the Layer-Property Flow (LPF) package (Harbaugh, 2005). Inter-cell conductances typically are computed from harmonic means of adjacent transmissivities in cells by an internal flow package such as LPF and are tracked within MODFLOW. The Horizontal Flow Barrier (HFB) Package (Hsieh and Freckleton, 1993) can modify specific inter-cell conductances that were computed by the Block-Centered Flow (BCF), Hydrogeologic-Unit Flow (HUF), or LPF packages. This alters the simulated transmissivities of adjacent cells.

Simulated transmissivities are sampled from cells in the regional model at locations where pumping during an aquifer test affected water levels. Simulated drawdowns in excess of a user-specified drawdown threshold define the sampled volume. This becomes a line of equal drawdown in the site model, which is discussed as the simulated drawdown profile. The sampled volume in the regional model is delineated by rotating the simulated drawdown profile about the axis of the well that was pumped during the aquifer test (fig. 8). The program T-COMP_Extract identifies model cells that are within the volume and the fractional contribution of transmissivity in each cell (appendix C). Transmissivity is averaged within the maximum extent of a simulated drawdown profile in each regional model layer. The vertical fraction of a regional model layer sampled is proportional to the fraction of the drawdown profile from the site model that intersects the regional model layer.

Areas affected by pumping also are identified with simulated lateral flow rates because investigated distances can be limited in unconfined aquifers. For example, a well that penetrates unconfined (layers 1 and 2) and confined (layers 5 and 6 ) aquifers is pumped $250 \mathrm{gal} / \mathrm{min}$ for 2 days (fig. 9). The resulting drawdown profile is within $300 \mathrm{ft}$ of the pumping well in the unconfined aquifer and extends more than 3,000 $\mathrm{ft}$ from the pumping well in the confined aquifer (fig. 9). Simulated lateral flow across the drawdown profile from the site model shows that similar transmissivities exist in both aquifers.

Transmissivity is sampled from a regional model layer if simulated lateral flow in a layer exceeds a lateral-flow threshold. This threshold is user-defined and a fraction of the maximum lateral flow in the vertical profile. Regional model layers $1,2,5$, and 6 would be sampled and transmissivity from other layers would be excluded in the previous example if the lateral-flow threshold were between 1 and 60 percent (fig. 9). A lateral-flow threshold greater than 60 percent also would exclude sampling regional model layer 1 .

Results of intersecting the simulated drawdown profile with the regional model are reported by the program T-COMP_Extract as a list of regional model cell numbers and fractional contribution of transmissivity for each cell. This file is discussed as the transmissivity-factors file. The transmissivity contribution from a regional model cell is the area that intersects the maximum extent of a drawdown profile divided by the area of the circle in a regional model layer (fig. 10). Fractional contributions from cells sum to the vertical fraction of the regional model layer that was intersected by the drawdown profile from the site model. This results in averaging transmissivities in a layer and summing the average transmissivity of each contributing regional model layer. The summation of all cell transmissivities times their fractional contribution is the simulated transmissivity that is compared to aquifer-test results.

Simulated transmissivities are sampled during model calibration with the program T-COMP_Simulated that integrates cell transmissivities into a single simulated transmissivity at each aquifer-test site (appendix C). Simulated transmissivities sample the cumulative results of all MODFLOW packages that affect horizontal inter-cell transmissivities. Simulated transmissivity and log-transmissivity are reported for each aquifer-test result. Input files for T-COMP_Simulated are the regional MODFLOW-name file and the transmissivity-factors file that was written by the program T-COMP_Extract. 
$\boldsymbol{A}$

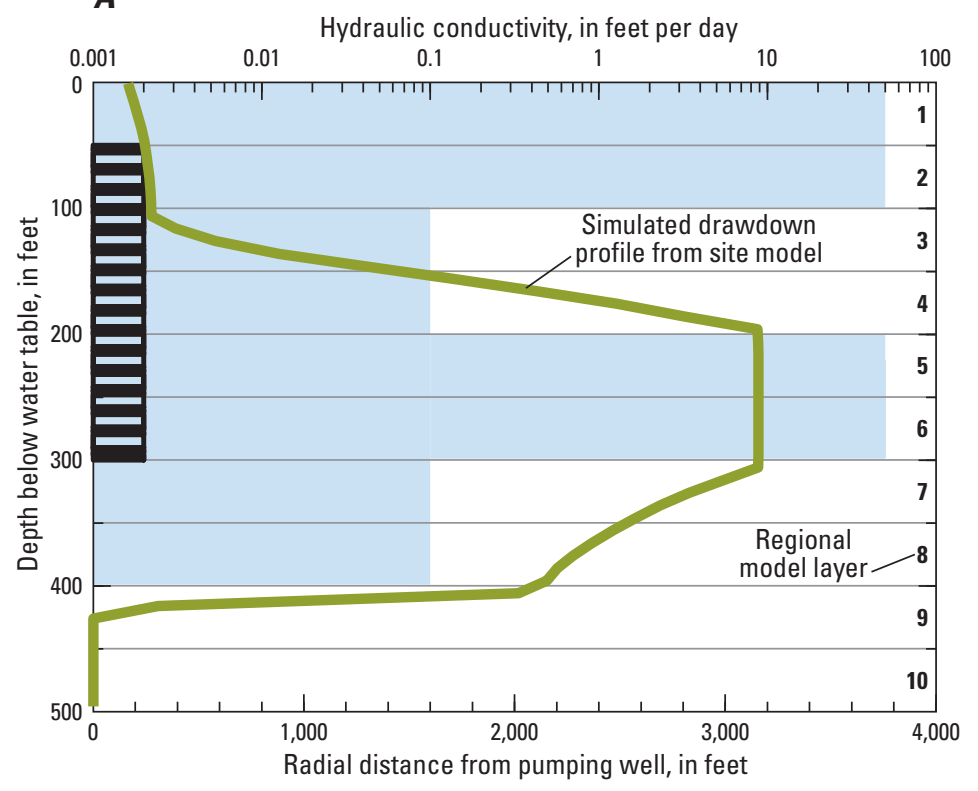

B

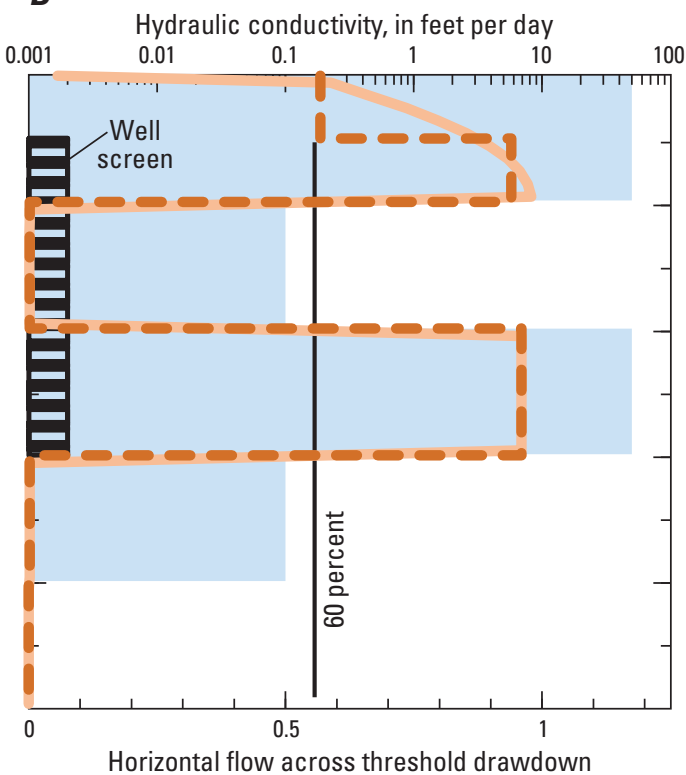

EXPLANATION

Hydraulic conductivity, in feet per day

Horizontal flow simulated with site model

Horizontal flow averaged by regional model layers

Figure 9. Vertical distribution of hydraulic conductivity and well construction with $(A)$ simulated drawdown profile from site model and $(B)$ simulated lateral flow across drawdown profile from site model, simulated lateral flow from site model averaged by regional model layer, and lateral-flow threshold.
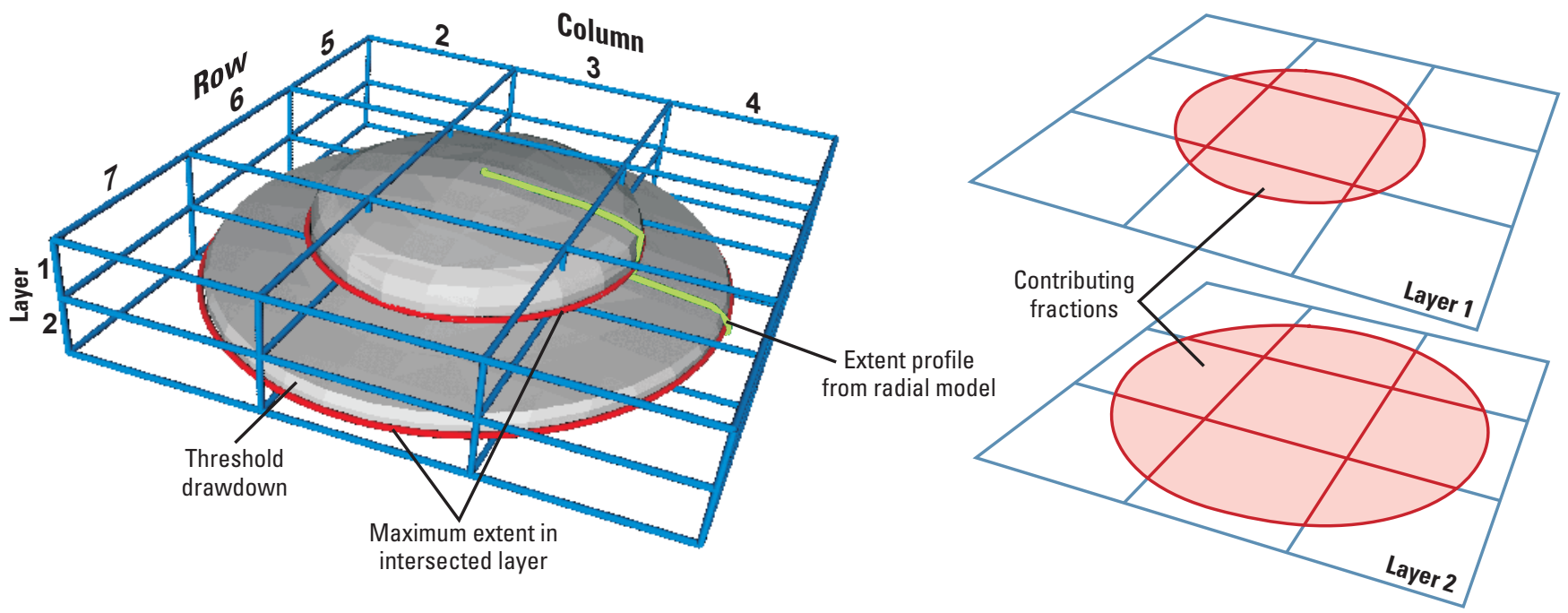

Figure 10. Intersection of investigated volume from an aquifer test with a model grid. 


\section{Validation}

The T-COMP approach was validated with hypothetical aquifer systems where hydraulic properties were specified and known. The hypothetical aquifer systems were simulated with regional models. Specified transmissivities in the regional models were compared to simulated transmissivities that were sampled with the T-COMP approach. Transmissivities also were estimated by interpreting drawdown in pumping wells (Cooper and Jacob, 1946) that were simulated with site models. Differences between Cooper-Jacob estimates and specified transmissivities represent biases that likely exist between aquifer-test results and field conditions (Halford and others, 2006).

\section{Simulation of Hypothetical Aquifer Systems}

Hypothetical aquifer systems were comprised of two aquifers that were separated by a leaky confining unit and underlain by a low-permeability unit (fig. 11; appendix D). Aquifers were assigned hydraulic conductivities of 5, 10, 20,50 , or $100 \mathrm{ft} / \mathrm{d}$, whereas confining units were assigned hydraulic conductivities of $0.01,0.1$, or $1 \mathrm{ft} / \mathrm{d}$ (fig. 11). Water table or confined conditions were simulated by assigning the upper $50 \mathrm{ft}$ as either an aquifer or confining unit, respectively. A hydraulic conductivity of $0.001 \mathrm{ft} / \mathrm{d}$ was assigned to the underlying low-permeability unit. Representative values of $2 \times 10^{-6} 1 / \mathrm{ft}, 0.15$, and 10 were assigned for specific storage, specific yield, and horizontal-to-vertical anisotropy, respectively, in all aquifer systems. These specified hydraulic properties are herein referred to as known hydraulic properties that were limited to plausible ranges. Known transmissivities ranged from 252 to $20,100 \mathrm{ft}^{2} / \mathrm{d}$ (appendix E).

All single-well tests were simulated over 2-day periods to balance testing effectiveness and operational constraints for confined and unconfined conditions. Pumping wells were screened in the upper aquifer, lower aquifer or both aquifers (table 1, fig. 11). All partially penetrating wells were open at the top of the aquifer or water table. Transmissivity estimates from tests of longer than 2 days would be less ambiguous because drainage from the water table could be observed. In practice, single-well tests typically range between 1 and 3 days because of operational constraints (Halford and others, 2006).
Table 1. Hydraulic properties and well construction that were varied in hypothetical models.

[A lateral-flow threshold of 0.1 of the maximum lateral flow across the drawdown threshold was used for all hypothetical models]

\begin{tabular}{lr}
\hline \multicolumn{1}{c}{ Investigated property } & Tested values \\
\hline $\begin{array}{l}\text { Screened Intervals, feet } \\
\text { below land surface }\end{array}$ & $50-100$, \\
& $200-300$, \\
& $50-300$ \\
Drawdown threshold, feet & $0.2,0.5,1.0$ \\
Hydraulic conductivity of & $5,10,20,50,100$ \\
$\quad$ aquifers, feet per day & \\
Hydraulic conductivity of & \\
confining units, feet per day & $0.01,0.1,1$ \\
\hline
\end{tabular}

Regional models were discretized coarser than site models. Regional models simulated $45 \mathrm{mi}^{2}$ areas that were divided into 71 rows of 71 columns with uniform cells of $500 \mathrm{ft}$ on a side. Aquifers and confining units that were $100 \mathrm{ft}$ thick were subdivided into 50-ft thick layers in the regional models (fig. 11). Site models extended 150,000 ft from the production well along a row that was discretized into 49 columns. Columns 1 and 2 that simulated the pumping well and annular fill were each $0.5 \mathrm{ft}$ wide. The remaining columns uniformly expanded 1.27 times the width of the previous column. Aquifers and confining units were subdivided vertically into $10-\mathrm{ft}$ thick layers in the site models (fig. 11). 


\section{Interpretation and Comparison}

About 93 percent of 270 simulated transmissivities that were sampled with the T-COMP approach were within a factor of 2 of specified transmissivities (fig. 12). A slight bias existed where specified transmissivities less than $2,000 \mathrm{ft}^{2} / \mathrm{d}$ were overestimated and specified transmissivities greater than $8,000 \mathrm{ft}^{2} / \mathrm{d}$ were underestimated. Biases averaged 20 percent for overestimates and 10 percent for underestimates.

Simulated transmissivities for a given hypothetical aquifer system were similar regardless of drawdown thresholds of 0.2 , 0.5 , or $1 \mathrm{ft}$ (appendix E).

Transmissivities also were estimated by interpreting drawdown in pumping wells (Cooper and Jacob, 1946) that were simulated with site models. Transmissivities of each hypothetical aquifer system were estimated at early and late times, where early time was the first 2 hours of pumping and late time began after the first day of pumping (fig. 13). Early-time and late-time periods were interpreted because drawdown declines in unconfined aquifers are segments of parallel straight lines connected by a flatter segment rather than a single straight line on a semi-log plot. Ambiguities frequently exist during both periods when interpreting drawdowns. Wellbore storage masks aquifer responses during early times. Drainage at the water table might not dominate late-time responses because transitioning from compressibility dominated storage to drainage frequently takes more than 2 days.

Cooper-Jacob transmissivity estimates also deviated slightly from specified transmissivities, but 87 percent of estimated and specified transmissivities differed less than a factor of 2 (fig. 12). Cooper-Jacob transmissivity estimates at early times underestimated specified transmissivities less than $2,000 \mathrm{ft}^{2} / \mathrm{d}$ by about 6 percent and overestimated specified transmissivities greater than $8,000 \mathrm{ft}^{2} / \mathrm{d}$ by 8 percent. Cooper-Jacob transmissivity estimates at late times consistently overestimated specified transmissivities by about 40 percent (fig. 12). Cooper-Jacob transmissivity estimates at late times are still more likely to be reported, despite potential bias, because wellbore storage effects have dissipated and a greater volume of aquifer has been investigated.

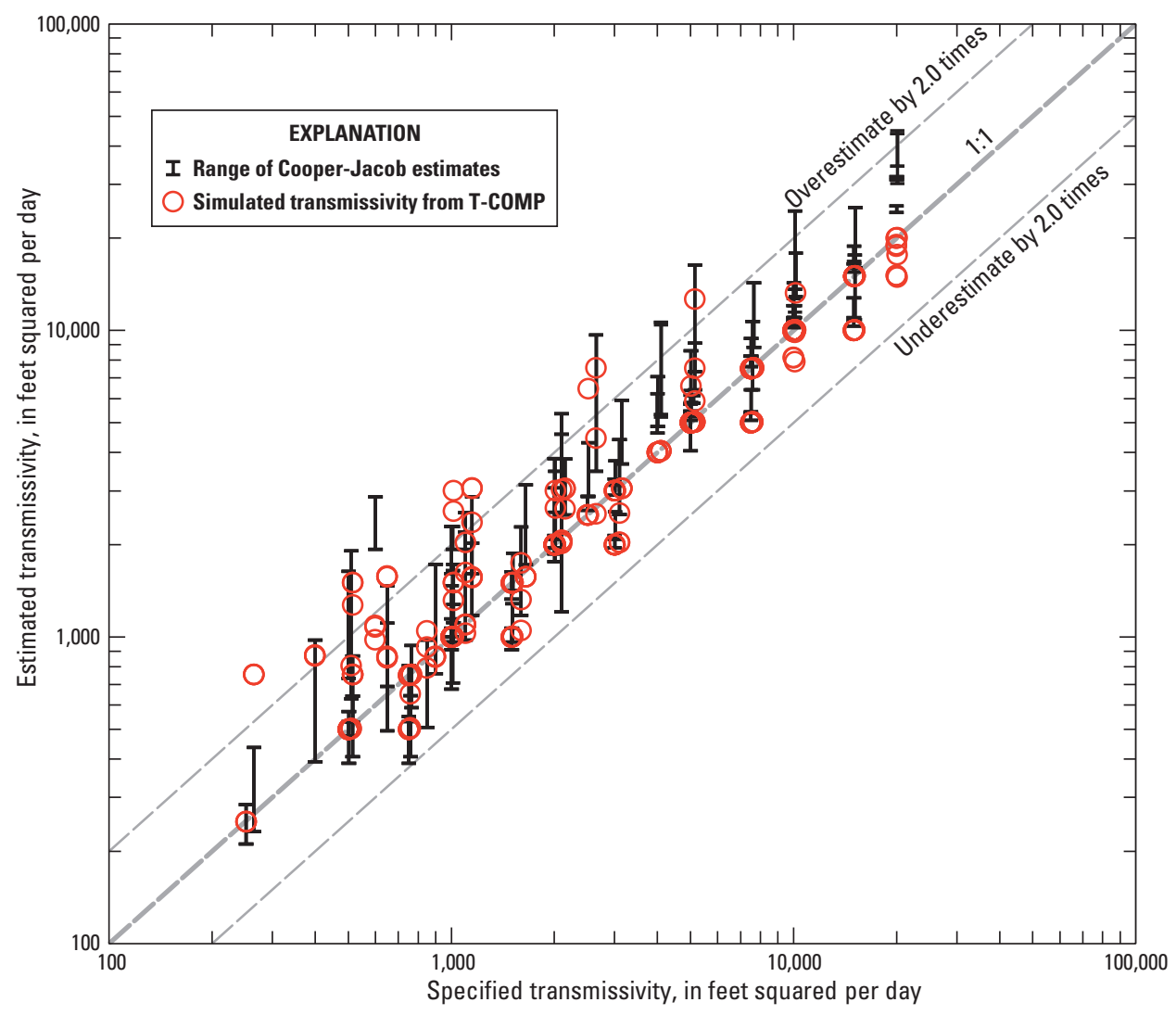

Figure 12. Transmissivity specified in hypothetical models compared to transmissivity estimated with Cooper-Jacob method and sampled with T-COMP approach. 


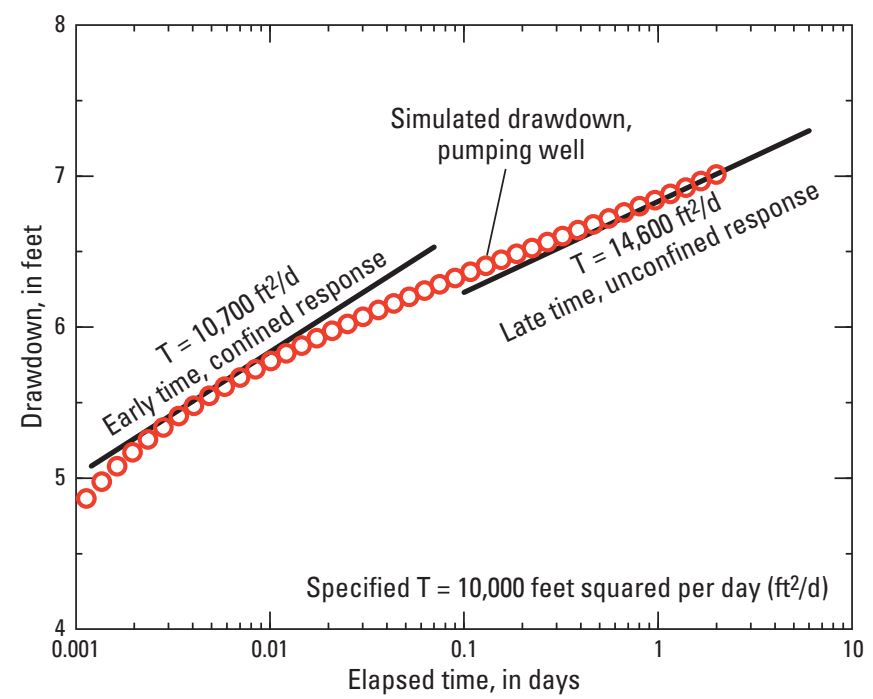

Figure 13. Simulated drawdown from a site model of an unconfined aquifer analyzed with the Cooper-Jacob method at early and late times (See figure 9 for specified hydraulic properties and well construction).

Differences between simulated and specified transmissivities were similar to differences between Cooper-Jacob estimates and specified transmissivities. Minimal differences and slight biases suggest that errors associated with sampling simulated transmissivities were no worse than between aquifer-test results and field conditions. Typical twofold differences between simulated and specified transmissivities were exceedingly trivial compared to greater than hundredfold differences between most probable transmissivities from hydraulic-conductivity limits and aquifer-test results (fig. 7).

\section{Conclusions}

Categorizing aquifer-test results by hydrogeologic unit significantly biases and poorly constrains simulated transmissivities. Probability distributions of transmissivities from hydraulic-conductivity limits consistently are skewed greater than aquifer-test results and 95-percent confidence intervals span multiple orders of magnitude. Most probable transmissivity at a site is predicted poorly by hydraulic-conductivity limits. Predictive errors increased greatly where transmissivity estimates from aquifer tests were less than 1,000 feet squared per day. Most probable transmissivity estimates of 30 and 140,000 feet squared per day from aquifer tests and hydraulic-conductivity limits, respectively, in a well with more than 9,000 feet of open hole suggest that differences in contributing thicknesses are a minor source of error.
Simulated transmissivities are computed and sampled quickly from regional MODFLOW models with T-COMP, a suite of FORTRAN programs. Investigated volumes of aquifer tests are estimated with site models that honor lithologic classifications from drillers' logs or a geologic framework. Transmissivities of regional model cells are sampled within the volume affected by an aquifer test. Simulated transmissivities are sampled from horizontal inter-cell transmissivities so that transmissivity estimates are independent of individual MODFLOW packages. Simulated transmissivity and log-transmissivity are reported for each aquifer-test result.

Simulated transmissivities that are sampled with the T-COMP approach represent field conditions within the accuracy of aquifer-test results. Simulated and specified transmissivities differed by less than a factor of 2 for more than 90 percent of 270 hypothetical aquifer systems that were tested. Transmissivities also were estimated with Cooper-Jacob analyses that also differed slightly from specified transmissivities in the hypothetical aquifer systems. Differences between Cooper-Jacob estimates and specified transmissivities were indicative of likely differences between aquifer-test results and field conditions. These differences were slight because 87 percent were less than a factor of 2 . These results demonstrate that field estimates and simulated transmissivities should be compared when calibrating groundwater flow models.

\section{References Cited}

Anderson, M.P., and Woessner, W.W., 1992, Applied groundwater modeling-Simulation of flow and advective transport: San Diego, Academic Press, 381 p.

Belcher, W.R., ed., 2004, Death Valley regional ground-water flow system, Nevada and California-Hydrogeologic framework and transient ground-water flow model: U.S. Geological Survey Scientific Investigations Report 20045205, 408 p.

Belcher, W.R., Sweetkind, D.S., and Elliott, P.E., 2002, Probability distributions of hydraulic conductivity for the hydrogeologic units of the Death Valley regional groundwater flow system, Nevada and California: U.S. Geological Survey Water-Resources Investigations Report 02-4212, $24 \mathrm{p}$.

Belcher, W.R., Elliott, P.E., and Geldon, A.L., 2001, Hydraulic-property estimates for use with a transient ground-water flow model for the Death Valley regional ground-water flow system, Nevada and California: U.S. Geological Survey Water-Resources Investigations Report 01-4210, 33 p., http://water.usgs.gov/pubs/wri/wri014210/. 
Bohling, G.C., and Butler, J.J., 2010, Inherent Limitations of Hydraulic Tomography: Groundwater, v. 48, p. 809-824, doi: 10.1111/j.1745-6584.2010.00757.x.

Brooks, L.E., Masbruch, M.D., Sweetkind, D.S., and Buto, S.G., 2014, Steady-state numerical groundwater flow model of the Great Basin carbonate and alluvial aquifer system: U.S. Geological Survey Scientific Investigations Report 2014-5213, 124 p., 2 pls., http://dx.doi.org/10.3133/ sir20145213.

Cooper, H.H., and Jacob, C.E., 1946, A generalized graphical method for evaluating formation constants and summarizing well field history, American Geophysical Union Transactions, v. 27, p. 526-534.

Domenico, P.A., and Schwartz, F.W., 1990, Physical and chemical hydrogeology: New York, John Wiley \& Sons, $824 \mathrm{p}$.

Fenelon, J.M., Sweetkind, D.S., and Laczniak, R.J., 2010, Groundwater flow systems at the Nevada Test Site, Nevada: A synthesis of potentiometric contours, hydrostratigraphy, and geologic structures: U.S. Geological Survey

Professional Paper 1771, 54 p., 6 pls.

Halford, K.J., Laczniak, R.J., and Galloway, D.L., 2005, Hydraulic characterization of overpressured tuff in central Yucca Flat, Nevada Test Site, Nevada: U.S. Geological Survey Scientific Investigations Report 2005-5211, 36 p., http://pubs.usgs.gov/sir/2005/5211/.

Halford, K.J., Weight, W.D., and Schreiber, R.P., 2006, Interpretation of transmissivity estimates from single-well pumping aquifer tests: Groundwater, v. 44, p. 467-471, doi: 10.1111/j.1745-6584.2005.00151.x.

Hanson, R.T., and Nishikawa, T., 1996, Combined use of flowmeter and time-drawdown data to estimate hydraulic conductivities in layered aquifer systems: Groundwater, v. 34, p. 84-94, doi: 10.1111/j.1745-6584.1996.tb01868.x.

Harbaugh, A.W., 2005, MODFLOW-2005, the U.S. Geological Survey modular ground-water model-The ground-water flow process: U.S. Geological Survey Techniques and Methods 6-A16, variously paged, http:// pubs.usgs.gov/tm/2005/tm6A16/.

Heath, R.C., 1983, Basic ground-water hydrology: U.S. Geological Survey Water-Supply Paper 2220, 86 p.
Hsieh, P.A., and Freckleton, J.R., 1993, Documentation of a computer program to simulate horizontal-flow barriers using the U.S. Geological Survey's modular three-dimensional finite-difference ground-water flow model: U.S. Geological Survey Open-File Report 92-477, 32 p.

Laczniak, R.J., Cole, J.C., Sawyer, D.A., and Trudeau, D.A., 1996, Summary of hydrogeologic controls on ground-water flow at the Nevada Test Site, Nye County, Nevada: U.S. Geological Survey Water-Resources Investigations Report 96-4109, 59 p.

Langevin, C.D., 2008, Modeling axisymmetric flow and transport: Groundwater, v. 46, p. 579-590, doi: 10.1111/j.1745-6584.2008.00445.x.

Navarro-Intera, 2013, Phase I flow and transport model document for corrective action unit 97-Yucca Flat/Climax Mine, Nevada National Security Site, Nye County, Nevada: Navarro-Intera Report, N-I/28091—080, Revision No. 0, $1,513 \mathrm{p}$.

Sandia National Laboratories, 2007, Saturated zone site-scale flow model, MDL-NBS-HS-000011 REV 03: Las Vegas, Nevada: Sandia National Laboratories, DIRS 177391 ACC: DOC.20070626.0004.

Southern Nevada Water Authority, 2009, Transient numerical model of groundwater flow for the Central Carbonaterock Province - Clark, Lincoln, and White Pine Counties Groundwater Development Project: Las Vegas, Nevada, Southern Nevada Water Authority, 394 p.

Stoller-Navarro Joint Venture, 2006, Groundwater flow model of corrective action units 101 and 102-Central and Western Pahute Mesa, Nevada Test Site, Nye County, Nevada: Stoller-Navarro Joint Venture Report, S-N/99205076, Revision No. 0, 1,101 p.

Straface, S., Yeh, T.-C.J., Zhu, J., Troisi, S., and Lee, C.H., 2007, Sequential aquifer tests at a well field, Montalto Uffugo Scalo, Italy: Water Resources Research, v. 43, W07432, doi:10.1029/2006WR005287.

Trinchero, P., Sanchez-Vila, X., Copty, N., and Findikakis, A., 2008, A new method for the interpretation of pumping tests in leaky aquifers: Groundwater, v. 46, p. 133-143, doi: 10.1111/j.1745-6584.2007.00384.x.

U.S. Geological Survey, 2013, Aquifer tests: Nevada Water Science Center Web page, accessed September 25, 2013, at http://nevada.usgs.gov/water/aquifertests/index.htm. 
T-COMP_A Suite of Programs for Extracting Transmissivity from MODFLOW Models

This page left intentionally blank 


\section{Appendixes}

\section{Appendix A. Aquifer Tests and Comparisons between Probability Distributions of Transmissivities from Hydraulic-Conductivity Limits and Aquifer-Test Results}

Wells and aquifer-test results used to estimate frequency of single-well aquifer tests, in section, Field Estimates-AquiferTest Results, are reported in the file 2013_NV-AquiferTestSUMMARY_Stats.xx. Probability distributions of transmissivities from hydraulic-conductivity limits and aquifer-test results for 49 wells (fig. 7) are reported in the file CompareT-PDFs AquiferTest+HydK-Limits.xlsm. Both files are in the zipped file, tm6A54_appendixa_AquiferTests+PDFs.zip, which can be accessed and downloaded at http://dx.doi.org/10.3133/tm6A54.

\section{Appendix B. T-COMP Programs, Pre-Processing Tools, and an Example}

T-COMPobserveMAKER is a workbook that will process aquifer-test data and create all necessary input files for the T-COMP programs. Necessary data are specified in a workbook that follows the template 01_Sample_T-COMPdata.xlsx. Macros interrogate a version of the workbook 01_Sample_T-COMPdata.xlsx and the NAME file of a regional MODFLOW model. Contents of all subdirectories are reported in README file in the root directory of the unzipped tm6a54_appendixb_TCOMP.v.1.00.zip file. Appendix B files can be accessed and downloaded at http://dx.doi.org/10.3133/tm6A54.

\section{Appendix C. Source Codes for T-COMP Programs}

Source codes for T-COMP programs are FORTRAN files in the zipped file, tm6a54_appendixc_Codes_T-COMP.v1.00. zip, which can be accessed and downloaded at http://dx.doi.org/10.3133/tm6A54. Contents of all subdirectories are reported in a README file in the root directory of the unzipped tm6a54_appendixc_Codes_T-COMP.v1.00.zip file.

\section{Appendix D. T-COMP_Compare-A Workbook for Comparing Simulated Transmissivities Sampled with T-COMP to Specified Values}

The Excel ${ }^{\circledR}$ program, T-COMP_Compare, FORTRAN executables, and MODFLOW templates for T-COMP_Create in the zipped file, tm6a54_appendixd_Regional-SiteCOMPARE.zip, can be accessed and downloaded at http://dx.doi.org/10.3133/ tm6A54. T-COMP_Compare is a workbook for simulating hypothetical aquifer tests in a regional model and sampling simulated transmissivities with the three T-COMP programs. Results from regional model, site model, and T-COMP output are summarized in a new workbook that displays simulated drawdowns during the aquifer test, well construction, and vertical profiles of hydraulic conductivity, lateral flow rates, and threshold drawdown. Contents of all subdirectories are reported in a README file in the root directory of the unzipped tm6a54_appendixd_Regional-SiteCOMPARE.zip file.

\section{Appendix E. Results from T-COMP Verification}

The Excel ${ }^{\circledR}$ summary file, Summary_HYPO-Aquifers.xlsx, and subdirectory of comparisons between simulated and specified transmissivities from 270 regional models in the zipped file, tm6a54_appendixe_Verification.zip, can be accessed and downloaded at http://dx.doi.org/10.3133/tm6A54. Contents of the summary file and results subdirectory are reported in a README file in the root directory of the unzipped tm6a54_appendixe_Verification.zip file. 

Publishing support provided by the U.S. Geological Survey

Science Publishing Network, Tacoma Publishing Service Center

For more information concerning the research in this report, contact the Nevada Water Science Center U.S. Geological Survey

2730 N. Deer Run Rd.

Carson City, NV 89701

http://nevada.usgs.gov/water/ 


\section{$\frac{\mathbb{2}}{3}$}

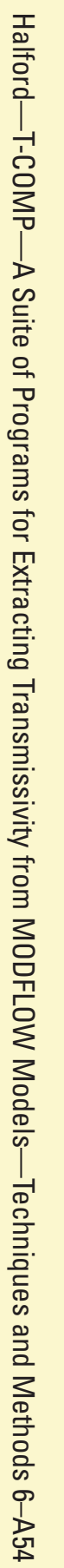

